\title{
Metal Ion Catalyzed Oxidation of $L$-Lysine by Alkaline Permanganate Ion-A Kinetic and Mechanistic Approach
}

\author{
B. MOHANTY ${ }^{\mathrm{a}}$, J. BEHERA ${ }^{\mathrm{a}}$, S. ACHARYA ${ }^{\mathrm{b}}$, P. MOHANTY ${ }^{\mathrm{a}}$ and A.K. PATNAIK ${ }^{\mathrm{c}}$ \\ ${ }^{a}$ P.G.Department of Chemistry, Utkal University, Bhubaneswar-751004, Odisha, India \\ ${ }^{\mathrm{b}}$ I.M.M.T, Bhubaneswar, Orissa, India \\ ${ }^{\mathrm{c}}$ P.G.Department of Chemistry, Ravenshaw University, Cuttack, Odisha, India \\ ajaypattanaik_kumar@yahoo.co.in
}

Received 1 July 2012 / Accepted 28 July 2012

\begin{abstract}
The kinetics of copper(II), nickel(II) and zinc(II) catalyzed oxidation of $L$-lysine by potassium permanganate in alkaline medium were studied spectrophotometrically. The reaction is first order with respect to [oxidant], [substrate] and [alkali] respectively. The results suggests the formation of a complex between the amino acid and lysine and the hydroxylated species of copper(II), nickel(II) and zinc(II). The reaction constants involved in the mechanism and the activation parameters have been calculated. The reactivity order of the catalyst is $\mathrm{Cu}(\mathrm{II})>\mathrm{Ni}$ (II) $>\mathrm{Zn}(\mathrm{II})$.
\end{abstract}

Keywords: Kinetics, Metal ion, Catalysed oxidation, L-lysine, Spectrophotometrically, Activation parameter

\section{Introduction}

The oxidation of organic compounds by permanganate ion depends on the nature of the substrate, the reactive species have the main role as the potential oxidant depending on the alkalinity of media. Among the six oxidation states of manganese $(+2$ to +7$)$ permanganate $\mathrm{Mn}(\mathrm{VII})$ is the most potent oxidation state in acid as well as in alkaline medium ${ }^{1-3}$. The mechanism by which the multivalent oxidant oxidizes substrate depends not only on the substrate but also on the medium ${ }^{4}$ used for the study. In strongly alkaline medium, the stable reduction products ${ }^{5,6}$ of the permanganate ion $\left(\mathrm{MnO}_{4}{ }^{-}\right)$is manganate ion $\left(\mathrm{MnO}_{4}{ }^{2-}\right)$. No mechanistic information is suitable to distinguish between a direct one-electron reduction to $\mathrm{Mn}(\mathrm{VI})$ and a mechanism, in which a hypomanganate is formed in a two electron reduction followed by rapid oxidation of the hypomanganate ion ${ }^{7}$. Studies of amino acids become important because of their biological significance and selectivity toward the oxidants and their ability to yield different products.

The substrate $L$-lysine is a necessary building block for all protein in the body. $L$-lysine plays a major role in calcium absorption and maintaining the correct nitrogen balance in the 
body and maintaining lean body mass. $L$-lysine is a basic amino acid and carries a +ve charge. In view of this, we undertook a study of the oxidation of $L$-lysine by $\mathrm{KMnO}_{4}$ in alkaline medium and also we compared uncatalysed and catalyzed reactions.

\section{Experimental}

Stock solution of $L$-lysine was prepared by dissolving the appropriate amount of sample in doubly distilled water. The solution of $\mathrm{KMnO}_{4}(\mathrm{BDH})$ was prepared and standardized by oxalic acid $\left[(\mathrm{COOH})_{2}\right]^{8}$. Potassium permanganate solution was prepared as described by Carrington and Symons ${ }^{9}$. Solutions of $\mathrm{CuSO}_{4}, \mathrm{NiSO}_{4}$ and $\mathrm{ZnSO}_{4}$ were prepared. $\left[\mathrm{Cu}^{++}\right]$in $\mathrm{CuSO}_{4}$ was determined iodometrically, $\left[\mathrm{Ni}^{++}\right]$in $\mathrm{NiSO}_{4}$ solution was determined gravimetrically as $\mathrm{Ni}(\mathrm{DMG})_{2}$ preparation method, $\left[\mathrm{Zn}^{++}\right]$in $\mathrm{ZnSO}_{4}$ solution was determined by EDTA titration.Ionic strength was adjusted with $\mathrm{NaClO}_{4}$.

\section{Kinetic studies}

Kinetic procedure followed as given in our earlier paper ${ }^{10}$. All kinetic measurements were performed under pseudo-first order conditions with $L$-lysine $\left(4 \times 10^{-4} \mathrm{~mol} \mathrm{dm}^{-3}\right.$ to $\left.1.2 \times 10^{-3} \mathrm{~mol} \mathrm{dm}^{-3}\right)$ having constant $\mathrm{KMnO}_{4}\left(2 \times 10^{-4} \mathrm{~mol} \mathrm{dm}^{-3}\right)$, ionic strength $\left(0.50 \mathrm{~mol} \mathrm{dm}^{-3}\right)$. The reaction was initiated by previously mixed thermally equilibrated solution of of $\mathrm{MnO}_{4}^{-}$, $\mathrm{Cu}(\mathrm{II}) / \mathrm{Ni}(\mathrm{II}) / \mathrm{Zn}(\mathrm{II})$ and $L$-lysine and required quantities of sodium hydroxide and sodium perchlorate at difference temperature ranges (273K - 308K).

The reaction was followed by monitoring the decrease in absorbance with time at $525 \mathrm{~nm}$ in Systronic UV-Vis spectrophotometer. The first order constants $\left(\mathrm{k}_{\mathrm{obs}}\right)$ were evaluated from the relationship.

$$
\ln \mathrm{I}\left(\mathrm{A}_{\mathrm{t}}-\mathrm{A}_{\infty}\right) \mathrm{I}=\ln \mathrm{I}\left(\mathrm{A}_{0}-\mathrm{A}_{\infty}\right) \mathrm{I}-\left(\mathrm{k}_{\mathrm{obs}}\right) . \mathrm{t}
$$

Where $A_{0}$, At, $A_{\infty}$ denote optical density of the reaction at zero time, time 't' and infinite time respectively. $A_{\infty}$ was measured after completion of the reaction. The correlation coefficients of plots used to determine $\left(\mathrm{k}_{\mathrm{obs}}\right)$ were found to be 0.99 in most of the cases.

\section{Stoichiometry}

The reaction mixtures containing an excess of potassium permanganate over $L$-lysine $\left(\mathrm{NH}_{2}\right.$ $\left.\left(\mathrm{CH}_{2}\right)_{4}-\mathrm{CH}\left(\mathrm{NH}_{2}\right)-\mathrm{COOH}\right)$ and $0.05 \mathrm{~mol} \mathrm{dm}^{-3}$ sodium hydroxide at a constant ionic strength of $0.5 \mathrm{~mol} \mathrm{dm}^{-3}$ was allowed to react for $2 \mathrm{~h}$ at $298 \mathrm{~K}$ under inert atmosphere.

The results showed that two moles of $\mathrm{MnO}_{4}{ }^{-}$were consumed by one mole of $L$-lysine. The main reaction products were identified as corresponding acetaldehyde ${ }^{11}$ by boiling point, spot test and ammonia ${ }^{12 \mathrm{a}}$ by Nessler's reagent and manganate by its visible spectra. $\mathrm{CO}_{2}$ was qualitatively detected by lime water test ${ }^{12 b}$. The product aldehyde was quantitatively estimated to about 78\% which is evidenced by its 2, 4 DNP derivative. The nature of the aldehyde was confirmed by its IR spectrum carbonyl stretching at $1729 \mathrm{~cm}^{-1}$ and a band at $2929 \mathrm{~cm}^{-1}$ due to the aldehydic $\mathrm{C}-\mathrm{H}$ stretching and a band at $3435 \mathrm{~cm}^{-1}$ indicating the presence of $\mathrm{NH}_{2}$ group ${ }^{13}$ (Figure 1). This product 5 -amino pentanal from $L$-lysine is also confirmed from the literature survey. The kinetic studies on the oxidation of $L$-lysine are somewhat limited, using oxidants like manganese triacetate $\mathrm{Mn}(\mathrm{OAc})_{3}{ }^{14 a}$, diperiodato argentite(III)[DPA $]^{14 \mathrm{~b}}$, diperiodato cuprate(III) $[\mathrm{DPC}]^{14 \mathrm{c}}$. In most of the studies 5-amino pentanal was found to be the product of oxidation of $L$-lysine. The stoichiometry of the reaction under kinetic study is

$\mathrm{NH}_{2}-\left(\mathrm{CH}_{2}\right)_{4}-\mathrm{CH}\left(\mathrm{NH}_{2}\right)-\mathrm{COOH}+2 \mathrm{MnO}_{4}^{-}+2 \mathrm{OH}^{-} \longrightarrow \mathrm{NH}_{2}-\left(\mathrm{CH}_{2}\right)_{4}-\mathrm{CHO}+2 \mathrm{MnO}_{4}^{2-}$

$+\mathrm{NH}_{3}+\mathrm{CO}_{2}+\mathrm{H}_{2} \mathrm{O}$ 


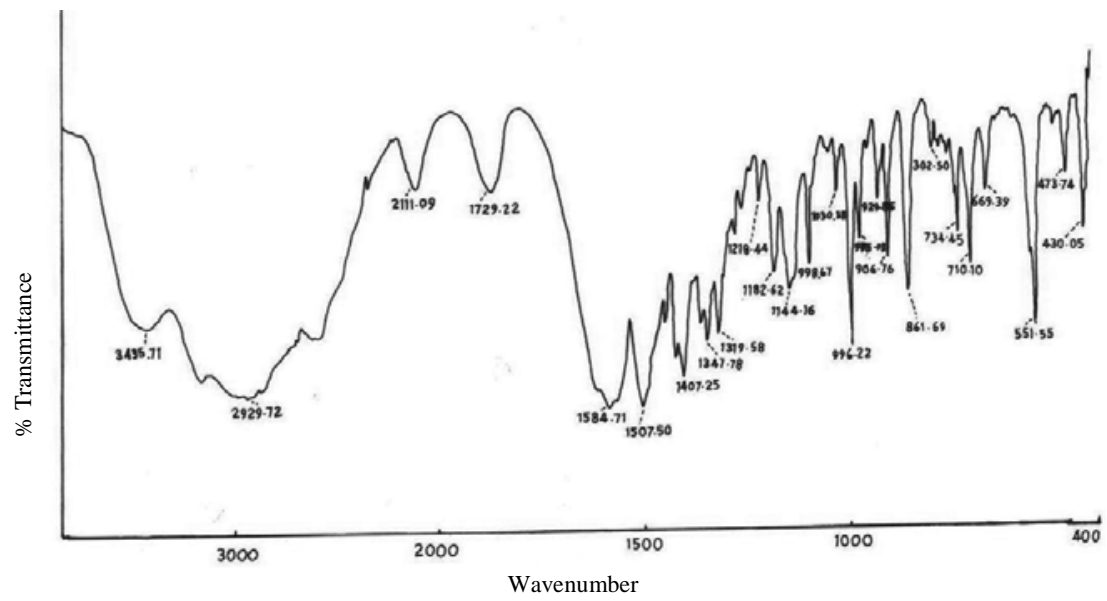

Figure 1. FTIR spectra of oxidation product of $L$-lysine

\section{Results and Discussion}

The permanganate in alkaline medium exhibits various oxidation states, such as Mn(VII), $\mathrm{Mn}(\mathrm{V})$ and $\mathrm{Mn}(\mathrm{VI})$. The solution changed from violet to blue and then to green excluding the accumulation of $\mathrm{Mn}(\mathrm{VII})$. The violet color originates from the pink of permanganate and blue from hypomanganate. The change of $\mathrm{KMnO}_{4}$ solution from violet $\mathrm{Mn}$ (VII) ion to dark green $\mathrm{Mn}(\mathrm{VI})$ ion through the blue $\mathrm{Mn}(\mathrm{V})$ has been observed. Mn(VII) decreases at $525 \mathrm{~nm}$ whereas $\mathrm{Mn}(\mathrm{VI})$ increases at 608nm during the reaction (Figure 2).

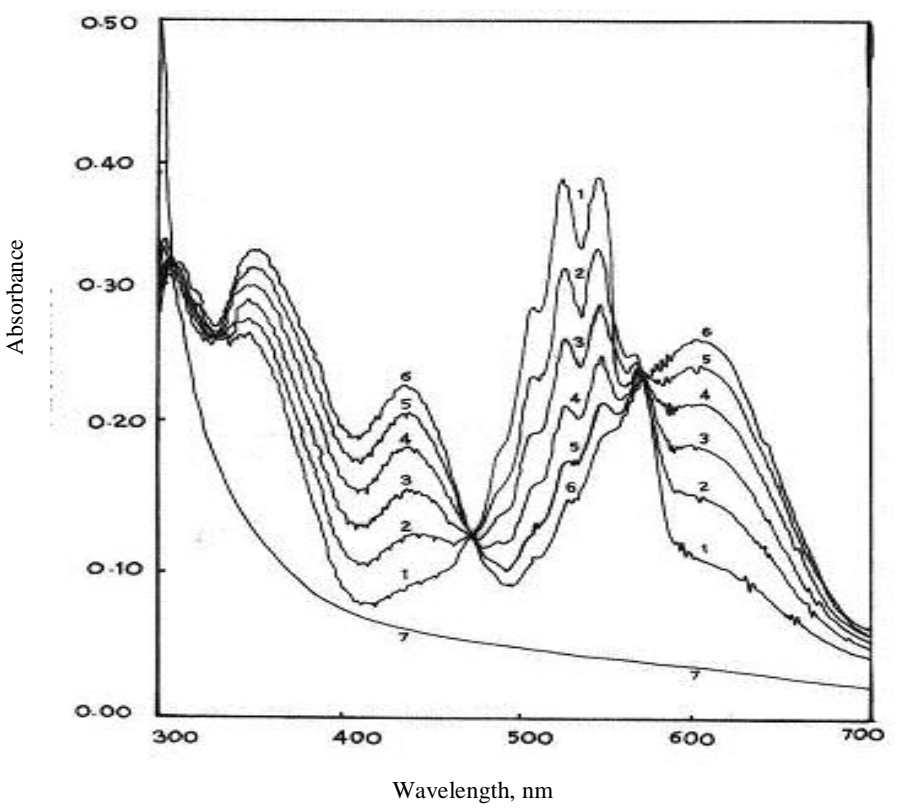

Figure 2. UV -Vis spectral scan of the reaction mixture of $[L$-lysine $]=1 \times 10^{-3} \mathrm{~mol} \mathrm{dm}^{-3}$ and $\left[\mathrm{KMnO}_{4}\right]=2 \times 10^{-4} \mathrm{~mol} \mathrm{dm}^{-3}, 1-0.5 \mathrm{~mol} \mathrm{dm}^{-3},[\mathrm{OH}]=5 \times 10^{-2} \mathrm{~mol} \mathrm{dm}^{-3}$ at $303 \mathrm{~K}$ at different time interval $\mathrm{t}=2 \mathrm{~min}(1-6)$ and after $24 \mathrm{~h} \mathrm{(7)}$ 
The order of the reaction was determined from the slopes of $\log \left(\mathrm{k}_{\mathrm{obs}}\right)$ versus $\log$ [concentration] plots by varying the concentration of reductant, catalyst and alkali at different temperatures from $293 \mathrm{~K}$ to $308 \mathrm{~K}$ while keeping others constant. The [Lysine] were varied from $4.0 \times 10^{-4}$ to $1.2 \times 10^{-3} \mathrm{~mol} \mathrm{dm}^{-3}$ and the $\left[\mathrm{OH}^{-}\right]$were varied from $1.0 \times 10^{-2}$ to $5.0 \times 10^{-2} \mathrm{~mol} \mathrm{dm}^{-3}$. The catalyst $\left[\mathrm{Cu}^{+2}\right]$ was varied from $2.31 \times 10^{-5}$ to $9.24 \times 10^{-5} \mathrm{~mol} \mathrm{dm}^{-3}$, $\left[\mathrm{Ni}^{+2}\right]$ catalyst was varied from $2.43 \times 10^{-5}$ to $9.72 \times 10^{-5} \mathrm{~mol} \mathrm{dm}{ }^{-3}$ and catalyst $\left[\mathrm{Zn}^{+2}\right]$ was varied from $2.2 \times 10^{-5}$ to $8.8 \times 10^{-5} \mathrm{~mol} \mathrm{dm}^{-3}$.

The pseudo-first order rate constant $\left(\mathrm{k}_{\mathrm{obs}}\right)$ increases with increasing $\left[\mathrm{Cu}^{+2}\right],\left[\mathrm{Ni}^{+2}\right]$ and $\left[\mathrm{Zn}^{+2}\right]$. M(II) forms two complexes as shown in Scheme 1 . The values of $K_{1}$ and $K_{2}$ are calculated which are very close to reported value ${ }^{13}$.

The rate constant $\left(\mathrm{k}_{\mathrm{obs}}\right)$ increased with increase in [alkali] and the order in the catalysts $\mathrm{Cu}(\mathrm{II}), \mathrm{Ni}(\mathrm{II})$ and $\mathrm{Zn}(\mathrm{II})$ were found to be unity. Under the conditions used the reaction rate of $\mathrm{Cu}(\mathrm{II})$ is more than that of $\mathrm{Ni}(\mathrm{II})$ which is compared to be more than $\mathrm{Zn}(\mathrm{II})$ (Table1).

Table 1. Effect of variation of [Lysine] \& $\left[\mathrm{OH}^{-}\right]$, at constant $\left[\mathrm{MnO}^{4-}\right]=2 \times 10^{-4}$ on $[\mathrm{Cu}(\mathrm{II})]=$ $4.62 \times 10^{-5},[\mathrm{Ni}(\mathrm{II})]=4.86 \times 10^{-5}$ and $\mathrm{Zn}(\mathrm{II})=4.4 \times 10^{-5}$ catalysed oxidation of $L$-lysine in aqueous alkaline medium at temp $293 \mathrm{~K}$ to $298 \mathrm{~K}$ and $\mathrm{I}=0.50 \mathrm{~mol} \mathrm{dm}^{-3}$

\begin{tabular}{ccccccc}
\hline $\begin{array}{c}10^{4}\left[\begin{array}{l}\text {-lysine }], \\
\text { mol dm }\end{array}\right. \\
4.0\end{array}$ & $\begin{array}{c}10^{2}\left[\mathrm{OH}^{-}\right], \\
\mathrm{mol} \mathrm{dm}^{-3}\end{array}$ & Temp, K & $\begin{array}{c}10^{4} \mathrm{k}_{\text {obs }}\left(\mathrm{S}^{-1}\right) \\
\text { without catalyst }\end{array}$ & $\begin{array}{c}\mathrm{Zn}^{++} \\
\text {with catalyst }\end{array}$ \\
\hline 6.0 & 1.0 & 293 & 0.88 & 1.05 & 2.00 & 2.27 \\
8.0 & 1.0 & 293 & 1.23 & 1.33 & 2.32 & 2.64 \\
10.0 & 1.0 & 293 & 1.55 & 1.67 & 2.65 & 2.95 \\
12.0 & 1.0 & 293 & 1.97 & 2.00 & 2.90 & 3.23 \\
4.0 & 1.0 & 293 & 2.30 & 2.35 & 3.20 & 3.34 \\
6.0 & 1.0 & 298 & 1.45 & 1.67 & 2.75 & 3.21 \\
8.0 & 1.0 & 298 & 1.85 & 2.00 & 3.08 & 3.57 \\
10.0 & 1.0 & 298 & 2.22 & 2.37 & 3.42 & 3.95 \\
12.0 & 1.0 & 298 & 2.64 & 2.72 & 3.67 & 4.25 \\
4.0 & 1.0 & 298 & 3.02 & 3.09 & 3.98 & 4.69 \\
6.0 & 1.0 & 303 & 2.45 & 2.75 & 3.85 & 4.64 \\
8.0 & 1.0 & 303 & 2.77 & 3.12 & 4.01 & 5.13 \\
10.0 & 1.0 & 303 & 3.17 & 3.45 & 4.32 & 5.40 \\
12.0 & 1.0 & 303 & 3.52 & 3.77 & 4.66 & 5.68 \\
4.0 & 1.0 & 303 & 3.95 & 4.10 & 4.91 & 5.92 \\
6.0 & 1.0 & 308 & 3.60 & 3.78 & 4.85 & 5.90 \\
8.0 & 1.0 & 308 & 3.97 & 4.08 & 5.16 & 6.20 \\
10.0 & 1.0 & 308 & 4.34 & 4.40 & 5.39 & 6.52 \\
12.0 & 1.0 & 308 & 4.66 & 4.72 & 5.68 & 6.82 \\
4.0 & 1.0 & 308 & 5.06 & 5.10 & 5.99 & 7.20 \\
6.0 & 2.0 & 293 & 1.27 & 1.51 & 2.45 & 2.70 \\
8.0 & 2.0 & 293 & 1.76 & 1.80 & 2.78 & 3.18 \\
10.0 & 2.0 & 293 & 1.98 & 2.06 & 3.02 & 3.32 \\
12.0 & 2.0 & 293 & 2.25 & 2.46 & 3.33 & 3.74 \\
4.0 & 2.0 & 293 & 2.72 & 2.82 & 3.65 & 3.85 \\
6.0 & 2.0 & 298 & 1.94 & 2.18 & 3.22 & 3.73 \\
& 2.0 & 298 & 2.27 & 2.52 & 3.55 & 4.05 \\
\hline & & & & & & $C o n t d \ldots$ \\
& & & & & &
\end{tabular}




\begin{tabular}{|c|c|c|c|c|c|c|}
\hline 8.0 & 2.0 & 298 & 2.63 & 2.80 & 3.80 & 4.41 \\
\hline 10.0 & 2.0 & 298 & 3.00 & 3.20 & 4.12 & 4.81 \\
\hline 12.0 & 2.0 & 298 & 3.47 & 3.57 & 4.45 & 5.18 \\
\hline 4.0 & 2.0 & 303 & 2.92 & 3.15 & 4.25 & 5.28 \\
\hline 6.0 & 2.0 & 303 & 3.29 & 3.63 & 4.55 & 5.77 \\
\hline 8.0 & 2.0 & 303 & 3.82 & 3.83 & 4.82 & 6.07 \\
\hline 10.0 & 2.0 & 303 & 4.00 & 4.15 & 5.10 & 6.27 \\
\hline 12.0 & 2.0 & 303 & 4.42 & 4.50 & 5.38 & 6.50 \\
\hline 4.0 & 2.0 & 308 & 4.10 & 4.26 & 5.32 & 6.52 \\
\hline 6.0 & 2.0 & 308 & 4.46 & 4.52 & 5.58 & 6.78 \\
\hline 8.0 & 2.0 & 308 & 4.82 & 4.88 & 5.58 & 6.78 \\
\hline 10.0 & 2.0 & 308 & 5.16 & 5.22 & 6.13 & 7.49 \\
\hline 12.0 & 2.0 & 308 & 5.55 & 5.60 & 6.46 & 7.72 \\
\hline 4.0 & 3.0 & 293 & 1.58 & 1.98 & 2.92 & 3.20 \\
\hline 6.0 & 3.0 & 293 & 1.90 & 2.24 & 3.18 & 3.66 \\
\hline 8.0 & 3.0 & 293 & 2.33 & 2.52 & 3.52 & 4.02 \\
\hline 10.0 & 3.0 & 293 & 2.88 & 2.92 & 3.75 & 4.27 \\
\hline 12.0 & 3.0 & 293 & 3.02 & 3.32 & 4.06 & 4.60 \\
\hline 4.0 & 3.0 & 298 & 2.29 & 2.66 & 3.68 & 4.31 \\
\hline 6.0 & 3.0 & 298 & 2.85 & 2.99 & 3.80 & 4.63 \\
\hline 8.0 & 3.0 & 298 & 3.12 & 3.29 & 4.28 & 4.80 \\
\hline 10.0 & 3.0 & 298 & 3.49 & 3.68 & 4.54 & 5.39 \\
\hline 12.0 & 3.0 & 298 & 3.83 & 4.07 & 4.85 & 5.72 \\
\hline 4.0 & 3.0 & 303 & 3.30 & 3.58 & 4.62 & 5.92 \\
\hline 6.0 & 3.0 & 303 & 3.70 & 4.06 & 4.90 & 6.37 \\
\hline 8.0 & 3.0 & 303 & 4.15 & 4.28 & 5.17 & 6.60 \\
\hline 10.0 & 3.0 & 303 & 4.45 & 4.60 & 5.45 & 6.90 \\
\hline 12.0 & 3.0 & 303 & 4.80 & 4.95 & 5.73 & 7.00 \\
\hline 4.0 & 3.0 & 308 & 4.55 & 4.74 & 5.70 & 6.95 \\
\hline 6.0 & 3.0 & 308 & 4.95 & 4.98 & 6.01 & 7.46 \\
\hline 8.0 & 3.0 & 308 & 5.40 & 5.42 & 6.28 & 7.72 \\
\hline 10.0 & 3.0 & 308 & 5.70 & 5.72 & 6.62 & 8.06 \\
\hline 12.0 & 3.0 & 308 & 6.05 & 6.10 & 6.92 & 8.27 \\
\hline 4.0 & 4.0 & 293 & 1.90 & 2.40 & 3.38 & 3.74 \\
\hline 6.0 & 4.0 & 293 & 2.26 & 2.68 & 3.52 & 4.24 \\
\hline 8.0 & 4.0 & 293 & 2.87 & 3.04 & 3.98 & 4.57 \\
\hline 10.0 & 4.0 & 293 & 3.10 & 3.42 & 4.19 & 4.82 \\
\hline 12.0 & 4.0 & 293 & 3.33 & 3.72 & 4.51 & 5.16 \\
\hline 4.0 & 4.0 & 298 & 2.68 & 3.13 & 4.15 & 4.89 \\
\hline 6.0 & 4.0 & 298 & 3.06 & 3.46 & 4.34 & 5.20 \\
\hline 8.0 & 4.0 & 298 & 3.47 & 3.79 & 4.75 & 5.39 \\
\hline 10.0 & 4.0 & 298 & 3.90 & 4.19 & 4.99 & 5.92 \\
\hline 12.0 & 4.0 & 298 & 4.18 & 4.50 & 5.31 & 6.33 \\
\hline 4.0 & 4.0 & 303 & 3.80 & 4.06 & 5.07 & 6.41 \\
\hline 6.0 & 4.0 & 303 & 4.18 & 4.50 & 5.35 & 7.00 \\
\hline 8.0 & 4.0 & 303 & 4.48 & 4.72 & 5.63 & 7.27 \\
\hline 10.0 & 4.0 & 303 & 4.85 & 5.12 & 5.90 & 7.53 \\
\hline
\end{tabular}




\begin{tabular}{ccccccc}
\hline 12.0 & 4.0 & 303 & 5.20 & 5.40 & 6.18 & 7.83 \\
4.0 & 4.0 & 308 & 5.10 & 5.16 & 6.17 & 7.42 \\
6.0 & 4.0 & 308 & 5.42 & 5.48 & 6.45 & 7.99 \\
8.0 & 4.0 & 308 & 5.78 & 5.80 & 6.73 & 8.25 \\
10.0 & 4.0 & 308 & 6.15 & 6.20 & 7.02 & 8.66 \\
12.0 & 4.0 & 308 & 6.50 & 6.55 & 7.36 & 8.92 \\
4.0 & 5.0 & 293 & 2.25 & 2.78 & 3.86 & 4.23 \\
6.0 & 5.0 & 293 & 2.58 & 3.08 & 3.98 & 4.81 \\
8.0 & 5.0 & 293 & 2.94 & 3.46 & 4.18 & 5.25 \\
10.0 & 5.0 & 293 & 3.38 & 3.82 & 4.56 & 5.43 \\
12.0 & 5.0 & 293 & 3.68 & 4.08 & 5.00 & 5.77 \\
4.0 & 5.0 & 298 & 3.25 & 3.56 & 4.63 & 5.46 \\
6.0 & 5.0 & 298 & 3.45 & 3.87 & 4.81 & 5.77 \\
8.0 & 5.0 & 298 & 3.82 & 4.23 & 5.04 & 6.04 \\
10.0 & 5.0 & 298 & 4.24 & 4.16 & 5.40 & 6.44 \\
12.0 & 5.0 & 298 & 4.58 & 4.93 & 5.80 & 6.90 \\
4.0 & 5.0 & 303 & 4.28 & 4.54 & 5.51 & 7.31 \\
6.0 & 5.0 & 303 & 4.61 & 4.82 & 5.80 & 7.83 \\
8.0 & 5.0 & 303 & 4.92 & 5.12 & 6.06 & 8.10 \\
10.0 & 5.0 & 303 & 5.28 & 5.48 & 6.38 & 8.21 \\
12.0 & 5.0 & 303 & 5.84 & 5.94 & 6.70 & 8.40 \\
4.0 & 5.0 & 308 & 5.60 & 5.66 & 6.61 & 8.12 \\
6.0 & 5.0 & 308 & 5.96 & 6.02 & 6.92 & 8.34 \\
8.0 & 5.0 & 308 & 6.27 & 6.31 & 7.17 & 8.76 \\
10.0 & 5.0 & 308 & 6.66 & 6.72 & 7.43 & 9.22 \\
12.0 & 5.0 & 308 & 7.00 & 7.08 & 7.76 & 9.52 \\
\hline
\end{tabular}

The rate constants $\mathrm{k}$ of the slow step of Scheme 1 were obtained from the intercept of the plots of $\left[\mathrm{M}(\mathrm{II}) /\left(\mathrm{k}_{\text {obs }}\right)\right]$ versus $1 /\left[\mathrm{L}\right.$-lysine] (where $\mathrm{M}=\mathrm{Cu}^{++}, \mathrm{Ni}^{++}$and $\mathrm{Zn}^{++}$) for different temperatures. The energy of activation corresponding to these constants was evaluated from the plot of log $\mathrm{k}$ versus $1 / \mathrm{T}$ from which the activation parameters were calculated (Table 2). A comparison of these values indicate that $\mathrm{Cu}(\mathrm{II})$ is more reactive as compared to $\mathrm{Ni}(\mathrm{II})$ and $\mathrm{Zn}(\mathrm{II})$ is less reactive as compared to $\mathrm{Ni}(\mathrm{II})$.

Table 2. Rate constant $\mathrm{k}$ for the reaction of $\mathrm{KMnO}_{4}$ with $L$-lysine at different temperatures and their activation parameters

\begin{tabular}{ccccc}
\hline Temp, $\mathrm{K}$ & $10^{4} \mathrm{k}\left(\mathrm{s}^{-1}\right)$ Copper(II) & Nickel(II) & $\left.10^{-1} \mathrm{k}^{-1}\right)$ Zinc(II) & Uncatalysed \\
\hline 293 & 4.39 & 1.55 & 1.57 & 1.68 \\
298 & 6.23 & 1.91 & 2.03 & 2.20 \\
303 & 6.63 & 2.05 & 2.08 & 2.25 \\
308 & 12.50 & 2.23 & 2.78 & 3.00 \\
\hline ncatalysed $-\Delta \mathrm{H}^{\#}\left(\mathrm{~kJ} \mathrm{~mol}^{-1}\right)$ & 47.00 & $\Delta \mathrm{S}^{\#}\left(\mathrm{~J} \mathrm{~K}^{-1} \mathrm{~mol}^{-1}\right)$ & -144.60 \\
atalysed- $\mathrm{Zn}(\mathrm{II})-\Delta \mathrm{H}^{\#}\left(\mathrm{~kJ} \mathrm{~mol}^{-1}\right)$ & 15.00 & $\Delta \mathrm{S}^{\#}\left(\mathrm{~J} \mathrm{~K}^{-1} \mathrm{~mol}^{-1}\right)$ & -170.50 \\
$\mathrm{Ni}(\mathrm{II})-\Delta \mathrm{H}^{\#}\left(\mathrm{~kJ} \mathrm{~mol}^{-1}\right)$ & 23.50 & $\Delta \mathrm{S}^{\#}\left(\mathrm{~J} \mathrm{~K}^{-1} \mathrm{~mol}^{-1}\right)$ & -151.50 \\
$\mathrm{Cu}(\mathrm{II})-\Delta \mathrm{H}^{\#}\left(\mathrm{~kJ} \mathrm{~mol}^{-1}\right)$ & 24.00 & $\Delta \mathrm{S}^{\#}\left(\mathrm{~J} \mathrm{~K}^{-1} \mathrm{~mol}^{-1}\right)$ & -149.90
\end{tabular}

Permanganate ion is a powerful oxidant in an aqueous alkaline medium. As it exhibits many oxidation states, the stoichiometric results play an important role. Under the prevailing experimental conditions at $\mathrm{pH}>12$, the reaction product of manganese(VII) is stable and further reduction of manganese (VI) might be stopped. The UV-Vis 2202 spectrophotometer 
studies have shown that at $\mathrm{pH}>12$, the product of manganese(VII) is manganese(VI) and no further reduction was observed as reported ${ }^{7}$. However on prolonged standing, green manganese (VI) is reduced to manganese (IV) under our experimental conditions. It is known that in aqueous solution, amino acid exists in zwitterionic ${ }^{15}$, whereas in aqueous alkaline medium it exists as anionic form according to the following equilibria.

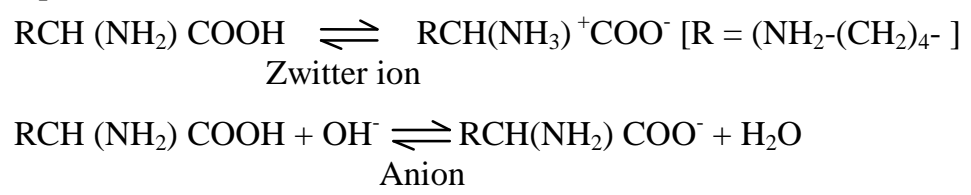

Mechanism of the reaction

Mechanism of the reaction shown in Scheme 1

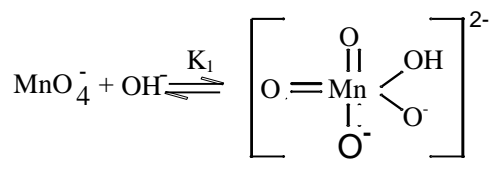

$$
\begin{aligned}
& \mathrm{R}-\underset{\mathrm{NH}_{2}}{\mathrm{CH}}-\mathrm{COO}^{-}+\left[\mathrm{M}\left(\mathrm{H}_{2} \mathrm{O}\right)\right]^{2+} \stackrel{\mathrm{K}_{2}}{\rightleftharpoons} \begin{array}{l}
\operatorname{Complex}(\mathrm{C})+\mathrm{H}_{2} \mathrm{O} \\
\left(\mathrm{M}=\mathrm{Cu}^{++}, \mathrm{Ni}^{++}, \mathrm{Zn}^{++}\right)
\end{array}
\end{aligned}
$$

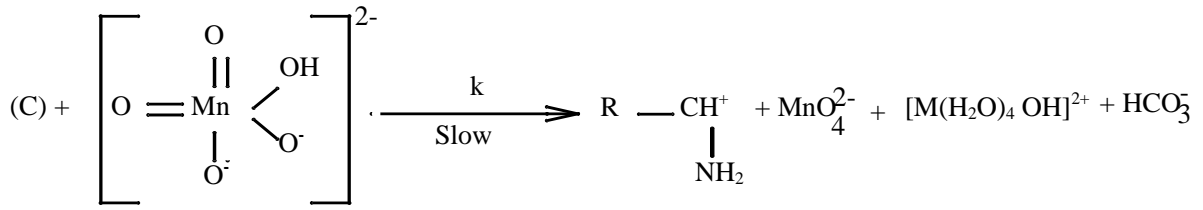

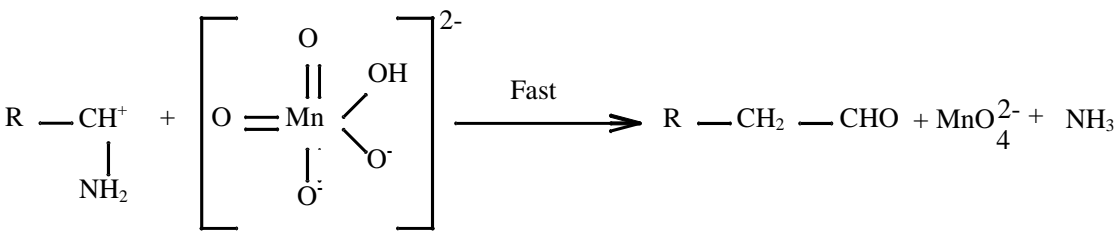

Scheme 1

The reaction between permanganate and $L$-lysine under study in alkaline medium has a 2:1 stoichiometry with a first order dependence on both the [alkali] and [ $L$-lysine]. Under the conditions $\left[\mathrm{OH}^{-}\right]>>[\mathrm{M}(\mathrm{II})], \mathrm{M}(\mathrm{II})$ is mostly present ${ }^{16}$ as the hydroxylated species, $\left[\mathrm{M}\left(\mathrm{H}_{2} \mathrm{O}\right)_{5} \mathrm{OH}\right]_{2}^{+}$. Increase in rate with increase in $\left[\mathrm{OH}^{-}\right]$indicates the presence of the hydroxylated species of $\mathrm{M}(\mathrm{II})$ as a reactive species, which is shown by following equilibria in accordance with the earlier work ${ }^{17}$.

$$
\left[\mathrm{M}\left(\mathrm{H}_{2} \mathrm{O}\right)_{6}\right]^{2+}+\mathrm{OH}^{-} \rightleftharpoons\left[\mathrm{M}\left(\mathrm{H}_{2} \mathrm{O}\right)_{5} \mathrm{OH}\right]^{+}+\mathrm{H}_{2} \mathrm{O} \text { (where } \mathrm{M}=\mathrm{Zn}^{++}, \mathrm{Ni}^{++} \text {and } \mathrm{Cu}^{++} \text {) }
$$

The results suggests the formation of a complex between the amino acid and the hydroxylated M(II) species. Such complex formation between substrate and catalyst has also been observed in earlier work ${ }^{18}$. The formation of the complex was also proved kinetically by the intercept of the plot of [M(II)]/ ( $\mathrm{k}_{\mathrm{obs}}$ ) versus 1/[L-lysine] (Figure 3 ). 


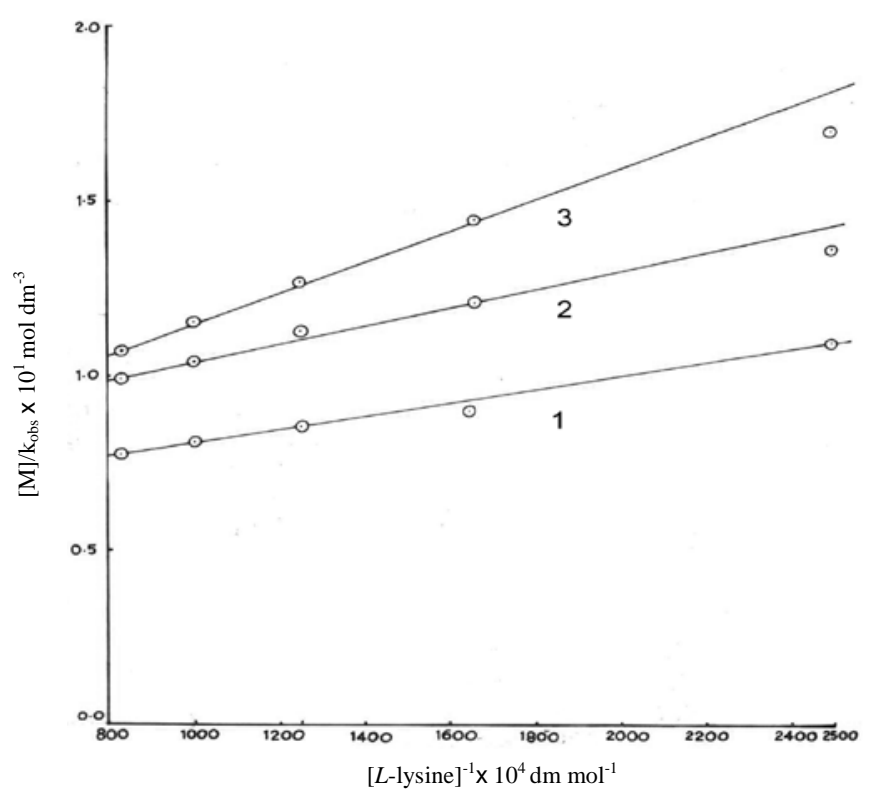

Figure 3. Plot of $\mathrm{M}(\mathrm{II}) / \mathrm{k}_{\mathrm{obs}}$ versus $1 /(L$-lysine) at $303 \mathrm{~K}$ where $\mathrm{M}(\mathrm{II})=\mathrm{Cu}(\mathrm{II})-1, \mathrm{Ni}(\mathrm{II})-2$, Zn(II) -3

Since Scheme 1 is in accordance with the generally well accepted principle of noncomplementary oxidations taking place in sequence of one electron steps, the reaction between the substrate and oxidant would afford a radical intermediate. A free radical scavenging experiment revealed such a possibility. This type of radical intermediate has also been observed in earlier work ${ }^{19}$ on the alkaline permanganate oxidation of amino acid. In agreement with the experimental results obtained, a mechanism as in Scheme 1 may be envisaged. The probable structure of the complex (C) is;

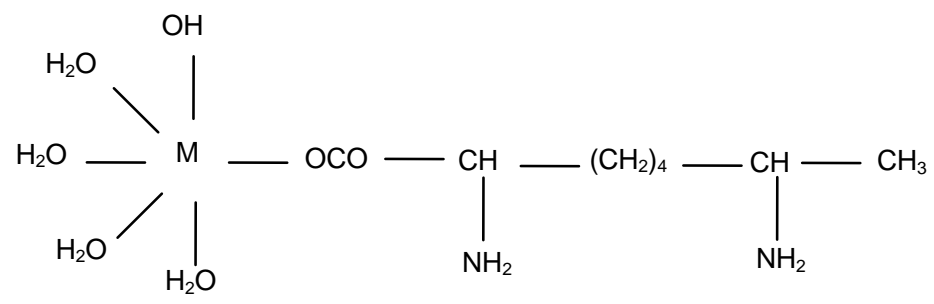

Scheme 1 Leads to rate law Equation (8),

$$
\left.\frac{\text { Rate }}{\left[\mathrm{MnO}_{4}\right]^{\prime}}=\mathrm{k}_{\mathrm{obs}}=\frac{\mathrm{k} \mathrm{K}_{1} \mathrm{~K}_{2}[\text { Lysine }][\mathrm{M}(\mathrm{II})][\mathrm{OH}]^{-}}{1+\mathrm{K}_{1}\left[\mathrm{OH}^{-}\right]+\mathrm{K}_{2}[\text { Lysine }]}+\mathrm{K}_{1} \mathrm{~K}_{2}[\mathrm{OH}]^{-} \text {[Lysine }\right]
$$

Equation (8) can be rearranged to Equation (9) as

$$
\frac{[\mathrm{M}]}{\mathrm{k}_{\mathrm{obs}}}=\frac{1}{\mathrm{k} \mathrm{K}_{1} \mathrm{~K}_{2}[\text { Lysine }][\mathrm{OH}]^{-}}+\frac{1}{\mathrm{kK}_{2}[\text { Lysine }]}+\frac{1}{\mathrm{k} \mathrm{K}_{1}[\mathrm{OH}]^{-}}+\frac{1}{\mathrm{k}}
$$


According to eq-3 the plots of $[\mathrm{M}] /\left(\mathrm{k}_{\mathrm{obs}}\right)$ versus $1 /[\mathrm{L}$-lysine $]$ and $[\mathrm{M}] /\left(\mathrm{k}_{\mathrm{obs}}\right)$ versus $1 /\left[\mathrm{OH}^{-}\right]$should be linear. From the slopes and intercepts of such plots, $K_{1}$, the equilibrium constant for the formation of alkaline species of the oxidant, $\mathrm{K}_{2}$, the formation constant of the complex between the catalyst and the substrate and $\mathrm{k}$, the rate constant of the rate limiting step are calculated at different temperatures. From the rate constant values, the activation parameters were calculated.

The moderate values of $\Delta \mathrm{H}^{\#} \& \Delta \mathrm{S}^{\#}$ favours electron transfer processes. The $\Delta \mathrm{H}^{\#}$ value was due to release of energy of solution changes in the transition state. The negative $\Delta S^{\#}$ within the range found for free radical reactions have been ascribed ${ }^{20}$ to the nature of the electron pairing and electron unpairing process and to the loss of a degree of freedom, formerly available to reactions on the formation of a rigid transition state.

Acceleration of the rate of oxidation reaction by using the catalysts $\mathrm{Cu}$ (II), $\mathrm{Ni}(\mathrm{II})$ \& $\mathrm{Zn}$ (II) due to reduce in their activation parameter and it is observed that the order of the reactivity is $\mathrm{Cu}(\mathrm{II})>\mathrm{Ni}(\mathrm{II})>\mathrm{Zn}(\mathrm{II})$. Copper is most effective catalyst because its activation parameter is reduced to greater extent.

The difference in the activation parameters for the catalysts $\mathrm{Cu}$ (II), $\mathrm{Ni}$ (II) \& $\mathrm{Zn}$ (II) explains that $\mathrm{Cu}(\mathrm{II})$ is more reactive as compared to $\mathrm{Ni}(\mathrm{II})$ and $\mathrm{Zn}(\mathrm{II})$ is less reactive as compared to $\mathrm{Ni}(\mathrm{II})$.

It is also interesting to note that the oxidant species $\left[\mathrm{MnO}_{4}^{-}\right]$required the $\mathrm{pH}>12$, as below this the reaction will proceed further to give $\mathrm{Mn}(\mathrm{IV})$, the reaction mixture slowly developing yellow turbidity. Thus, it becomes apparent that in carrying out this reaction the role of $\mathrm{pH}$ in the reaction medium is crucial.

\section{Acknowledgement}

Authors are thankful to Head of the Department of Chemistry, Utkal University, Vanivihar for providing facilities in the department.

\section{References}

1. Stewart R and Wiberg K B, (Ed.), Oxidations in Organic Chemistry, Part A, Academic Press, New York, 1965, Chapter 1.

2. Freeman F, Rev React Spec Chem React., 1976, 1, 179.

3. Lee D G, The Oxidations of Organic Compounds by Permanganate Ion and Hexavalent Chromium, Open court, La Salle, 1980.

4. Gardener K A, Kuehnert L I and Mayer J M, Inorg Chem., 1997, 36, 2069.

5. Simandi L I, Jaky M, Savage V R and Schelly Z A, J Am Chem Soc., 1985, 107, 422.

6. Timmanagoudar P L, Hiremath G A and Nandibewoor S T, Trans Met Chem., 1997, 22, 193; (b) Timmanagoudar P L, Hiremath G A and Nandibewoor S T, Pol J Chem., 1996, 70, 1459; (c) Nadimpalli S, Rallabandi R and Diksmitulu L S A, Trans Met Chem., 1993, 18, 510.

7. Balado A M, Galon B C and Marton F J P, Anal Quim., 1992, 88, 170; (b) Singh H S, Singh R K, Singh S M and Sisodia A K, J Phys Org Chem., 1997, 81, 1044-1047; (c) Panari R G, Harihar A L and Nandibewoor S T, J Phys Org Chem., 1999, 12, 340-346; (d) Nandibewoor S T, Hiremath G A and Timmagoudar P L, Trans Met Chem., 2000, 25, 394.

8. Jeffery G H, Bassett J, Mendham J and Denny R C, Vogel's Textbook of Quantitative Chemical Analysis, Fifth Ed., ELBS, Longman, Essen, UK, 1996, P. 371. 
9. Carrington A and Symons M C R, J Chem Soc., 1956, 3373.

10. Mohanty B, Behera J, Acharya S, Mohanty P, Pattnaik A K and Das S P, J Indian Chem Soc., 2011, 88(10), 1561-1566.

11. Feigi F, Spot tests in Organic Analysis, $7^{\text {th }}$ Ed., American Elsevier Scientific Publishing, Company New York, 1975, 195.

12 (a) A I. Vogel, Text Book of Quantitative Chemical Analysis, $5^{\text {th }}$ Ed., ELBS, Longman group UK, 1989, 371; (b) Das A K and Das M, J Chem Soc Dalton Trans., 1994, 589.

13. Chimatadar S A, Kini A K and Nandibewoor S T, Indian J Chem., 2003, 42(8)A, 1850-1855.

14 (a) Kanchugarakoppal S R, Siddegowda C and Dandinasivara S M, Transition Metal Chem., 1996, 21(6), 519-523; (b) Hosamani R R and Nandibewoor S T, J Chem Sci., 2009, 121(3), 275-281; (c) Kiran T S, Hiremath D C and Nandibewoor S T, Russian J Phys Chem A, 2007, 81(12), 2070-2077.

15. Chang R, Physical Chemistry with Applications to Biological Systems. (Mac Millan New York), 1981, 326.

16. (a) Uma V, Sethuram B and Rao T N, React Kinet Catal Lett., 1981, 18, 283-288; (b) Nandibewoor S T, Hiremath G A and Timmanagoudar P L, Trans Met Chem., 2000, 25, 394.

17. (a) Radhakrishnamurty P S and Panday H P, Bull Soc Kinet Ind., 1980, 2, 6; (b) Cotton F A and Wilkinson G, Advanced inorganic Chemistry (Wiley Eastern New York), 1966, 153; (c) Timmanagoudar P L, Hiremath G A and Nandibewoor S T, J Indian Chem Soc., 1997, 74, 296-298.

18. (a) Sengupta K K and Basu B, Indian J Chem., 1977, 15A, 108; (b) Upadhyaya S K and Agarwal M C, Indian J Chem., 1980, 19A, 478.

19. Saleem Md, Kembhabi R, Rafeek G Panari and Nandibewoor S T, Inorg React Mech., 1999, 1, 225-231.

20. Walling C, Free Radicals in Solutions (Academic Press, New York), 1957, 38. 